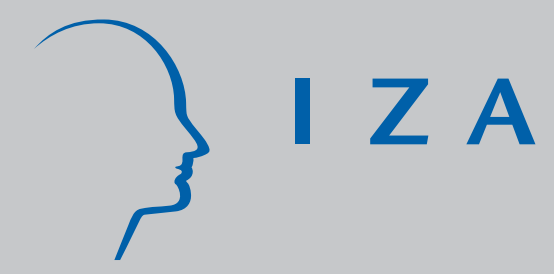

\begin{abstract}
IZA DP No. 153
Overtime Hours in Great Britain over the Period 1975-1999: A Panel Data Analysis
\end{abstract}

Adriaan S. Kalwij

Mary Gregory

May 2000 


\title{
Overtime Hours in Great Britain over the Period 1975-1999: A Panel Data Analysis
}

\author{
Adriaan S. Kalwij \\ Department of Economics, University of Oxford \\ Mary Gregory \\ Department of Economics, University of Oxford
}

Discussion Paper No. 153

May 2000

\author{
IZA \\ P.O. Box 7240 \\ D-53072 Bonn \\ Germany \\ Tel.: +49-228-3894-0 \\ Fax: +49-228-3894-210 \\ Email: iza@iza.org
}

This Discussion Paper is issued within the framework of IZA's research area The Welfare State and Labor Markets. Any opinions expressed here are those of the author(s) and not those of the institute. Research disseminated by IZA may include views on policy, but the institute itself takes no institutional policy positions.

The Institute for the Study of Labor (IZA) in Bonn is a local and virtual international research center and a place of communication between science, politics and business. IZA is an independent, nonprofit limited liability company (Gesellschaft mit beschränkter Haftung) supported by the Deutsche Post AG. The center is associated with the University of Bonn and offers a stimulating research environment through its research networks, research support, and visitors and doctoral programs. IZA engages in (i) original and internationally competitive research in all fields of labor economics, (ii) development of policy concepts, and (iii) dissemination of research results and concepts to the interested public. The current research program deals with (1) mobility and flexibility of labor markets, (2) internationalization of labor markets and European integration, (3) the welfare state and labor markets, (4) labor markets in transition, (5) the future of work, (6) project evaluation and (7) general labor economics.

IZA Discussion Papers often represent preliminary work and are circulated to encourage discussion. Citation of such a paper should account for its provisional character. 
IZA Discussion Paper No. 153

May 2000

\section{ABSTRACT \\ Overtime Hours in Great Britain over the Period 1975-1999: A Panel Data Analysis}

Around $40 \%$ of the male workforce regularly works 8 to 9 hours a week of paid overtime. This paper investigates the determinants of overtime hours in Britain over the period 1975-1999. For this purpose a panel data Tobit model is estimated using the very large panel of employees from the National Earnings Survey Panel Dataset.

The empirical results show that changes in the job-mix across the economy, from high to low overtime jobs rather than within-job changes in the use of overtime, account for most of the apparent decline in the extent of overtime working over the 1990s. Within jobs, the GDP cycle has a significant impact on overtime work, while labour market conditions, represented by the unemployment rate, do not. The elasticity of total working hours with respect to wages is found to be close to zero and with respect to contractual hours close to unity. Furthermore the results show that the decline of unionisation has not altered the use of overtime.

JEL Classification: C23, C33, C44, J00

Keywords: Overtime work, contractual hours, panel data Tobit model

Adriaan S. Kalwij

Department of Economics

University of Oxford

Manor Road

Oxford OX1 3UL

UK

Tel.:+44-1865-281168

Fax:+44-1865-271094

Email: adriaan.kalwij@economics.ox.ac.uk 
Over at least the last three decades in Britain the incidence of overtime and the number of hours of overtime work have remained persistently high. Through the 1980s around $40 \%$ of the fulltime male workforce were working paid overtime; this proportion declined somewhat over the 1990s, but was still 33\% in 1999. Both contractual hours and total working hours have a parallel downward trend over the last three decades but, for those who work overtime, the share of overtime hours in total working hours has remained fairly constant. For those who work overtime the average number of paid overtime hours has fluctuated cyclically, but has been consistently between 8 and 10 hours per week. Similar observations are made for the US (Trejo, 1991, 1993) and Germany (Bauer and Zimmermann, 1999, and Hunt, 1999). This indicates that paid overtime hours are a significant proportion of the hours worked, and, consequently, of the labour costs of firms and the labour income of households. Also it suggests that overtime hours are a permanent feature of employment and not only a tool for firms in dealing with cyclical variation in labour demand.

Given its demand for labour, the firm decides how to distribute this between workers and hours per worker. In Britain overtime hours are largely unregulated, giving firms exceptional flexibility in the use of overtime hours to match their demand for labour (see Bell and Hart, 1999). The fixed costs associated with a worker, hourly wage rates and standard hours of work have all have been argued to be important determinants of the firm's desired distribution of labour demand over workers and hours per worker (see, e.g. Calmfors and Hoel, 1988). In addition to the firm's desired hours per worker, actual hours of paid work are affected by the worker's willingness to supply these (see, e.g., Nickell, 1983). It is natural to think of overtime hours, i.e. hours worked in excess of contractual hours, as associated with the firm's response to labour demand shocks caused by shifts in product demand. However, empirical evidence suggests that structural shifts in labour demand are more likely to be dealt with by variation in the number of workers rather than in hours of work i.e. that the cyclical variation in working hours is relatively small, with only short run or within period fluctuations in labour demand met by the use of overtime hours (Lilien and Hall 1986).

This paper analyses paid overtime work in Britain over the period 1975-1999. The main contribution can be summarized as follows: A panel data Tobit model is estimated to analyse the effects of contractual hours, wage rates and union status on paid overtime hours. The occurrence 
and extent of overtime work is modelled as specific to the worker-job combination, comprising both labour demand and supply effects. In contrast to previous empirical studies, this econometric framework explicitly takes into account both the censoring of overtime hours at zero and worker-job specific effects that are allowed to correlate with the explanatory variables. This yields identification of the effects of time-varying explanatory variables on overtime work solely from within-job variation. Macroeconomic data on GDP and unemployment are used to assess the impact of the business cycle on overtime hours and whether there is any trend towards a reduction in overtime work over time. Finally, the empirical results identify the types of worker who work overtime. The data used are taken from the British New Earnings Panel Dataset (NESPD). These data are individual-level data, and the panel is available for the years 1975-99.

The remainder of the paper is structured as follows: Section 2 discusses previous empirical studies. Section 3 discusses the data. Section 4 describes the econometric framework for analysing overtime hours. Section 5 discusses the estimation results and section 6 concludes.

\section{Previous Empirical Studies}

Several studies have investigated the effects of changes in contractual hours and/or wage rates on overtime hours worked. Trejo (1993), using US cross-section data ${ }^{1}$, finds that a reduction in contractual hours results in an increase in paid overtime hours. Furthermore, he finds that an increase in the wage rate increases both the incidence of overtime and the number of overtime hours worked. Bell and Hart (1999), using British cross-section data ${ }^{2}$, similarly find a negative effect of contractual hours on paid overtime hours but, in contrast to Trejo, they find that an increase in the wage rate results in a decrease in paid overtime hours. Bauer and Zimmermann (1999), on the other hand, using data ${ }^{3}$ for Germany, find that a decrease in contractual hours decreases overtime work (including unpaid overtime hours). Since their study does not control for the change in wage rates implied by the change in contractual hours they cannot report on its impact. Each of these studies identifies the effects solely on cross-sectional variation ${ }^{4}$. Their results therefore basically identify which workers are likely to work overtime, rather than the

\footnotetext{
${ }^{1}$ May 1985 Current Population Survey.

21996 wave of the National Earnings Survey (NES).

3 1984-1997 waves of the German SocioEconomic Panel (GSOEP).

${ }^{4}$ Bauer and Zimmermann have panel data but their pooled Tobit model does not exploit this.
} 
causal effects of a reduction in standard hours or an increase in the wage rate on overtime hours worked.

Panel data may be used to overcome this problem. Bell and Hart (1998), using British data $^{5}$, analyse the influence of hourly wage rates on actual hours of work in a fixed effects model. Their main finding is that a rise in the hourly wage rate decreases total hours of work. They do not examine the impact on overtime hours directly, but use their estimates of a contractual hours equation and an actual hours equation to make inferences concerning overtime hours. Hunt (1999) takes as her focus of interest the effects of a reduction in contractual hours on overtime hours. Using German panel data ${ }^{6}$, she concludes that a one-hour reduction in standard hours leads to $0.88-1$ hour reduction in actual hours and that overtime hours are hardly affected by this. Like Bell and Hart (1998) she does not analyse overtime hours directly, but focuses on actual hours, with a linear probability model for the incidence of overtime, then using these results to make inferences about overtime hours. In contrast to Bell and Hart, Hunt does not control for wage effects in the hours equation. Although she notes in her argument that for workers on weekly, monthly or annual pay a decrease in standard hours implies a de facto increase in the hourly wage rate, her econometric framework does not allow for this simultaneity.

Both Bell and Hart (1998) and Hunt (1999) base their estimates on a fixed effects model, exploiting the availability of panel data. In each case the fixed effects are individual specific. The justification of this relies solely on labour supply considerations, and means that identification of the parameters results primarily from between-job variation rather than within-job variation. The approaches adopted also not take into account the fact that the distribution of overtime hours is truncated at zero, resulting in the distribution of actual hours conditional on contractual hours being censored at the level of contractual hours. Failure to take account of this yields inconsistent estimates (Tobin, 1958).

The approach adopted in this study aims to model overtime hours directly, including both contractual hours and basic wage rates are among the explanatory variables. To accommodate both demand and supply influences on overtime worked job-individual specific effects are introduced. These are allowed to correlate with the explanatory variables. We also extend the econometric framework employed in previous empirical studies by taking into account the truncation of overtime hours using a newly developed estimator.

\footnotetext{
5 1975-1994 waves of the National Earnings Survey (NES).

${ }^{6}$ 1984-1994 waves of the German Socio-Economic Panel (GSOEP).
} 
This study analyses paid overtime hours. Although from a welfare perspective unpaid overtime and shift work are of major importance they cannot be analysed in this paper since the necessary data are not available (see section 3). However, given the extent of paid overtime work, the analysis of this apparently important element of labour cost and source of household labour income is of interest in its own right. Confining the analysis to paid overtime yields a more clear-cut interpretation of the empirical results than if unpaid and paid overtime work were combined, as is often done. It does, however, blur the comparison with some previous studies.

3 The New Earnings Survey Panel Data 1975-1999 (NESPD)

The NESPD provides data on individual employees in employment in Britain. In principle all employees who have a National Insurance number that ends in a specified pair of digits are included in the sample, yielding a random sample of $1 \%$ of all workers in Britain. In each year the same specified digits are used to draw the sample, making it possible to construct the panel. The Survey questionnaire is directed to the worker's employer, who is legally obliged to complete the questionnaire from payroll records. The relevant questions on the individual's earnings and hours ask about total and overtime earnings, contractual (standard) working hours and paid overtime hours for the specific Survey week in April of each year. Furthermore, questions are asked about the employee's age, gender, union coverage, and occupation, along with the industrial classification and geographic location of the establishment. When this research was started all waves from 1975 to 1999 were available.

The Survey contains no information on the individual's educational attainment or on household characteristics such as the presence of children or marital status. For this reason the empirical analysis includes only male employees who are under 65 years of age. Individuals whose earnings are affected by absence are excluded from the sample, as are multiple jobholders and those who do not have specified contractual hours. These exclusions, together with missing values and inconsistencies in the individual's age or gender coding between years, eliminate around $20 \%$ of the potential sample. This yields an actual sample of about 72,000 individuals per year. In the empirical analysis only those individuals observed within a job in two consecutive periods can be used. This because the empirical analysis is based on a first difference equation, as will be discussed in section 4 . This results in a sample of about 47,000 individuals per year. 
The definitions of the relevant variables are as follows. The standard wage rate is defined as standard gross weekly earnings (i.e. total weekly earnings minus weekly overtime pay) divided by standard ('normal basic') working hours. All wage rates are in $1999 £ s$, with deflation by the retail price index. The share of overtime work is defined as weekly paid overtime hours divided by total paid hours. Union coverage is based on whether or not the pay and working conditions of the worker are set by a collective agreement. Note that overtime work in Britain is largely unregulated (see Bell and Hart (1999) for a more detailed discussion on this issue). The occupational classification is based on the 1992 Standard Occupational Classification at the level of 9 Major Groups. The industrial classification is based on the 1995 Standard Industrial Classification, at the one-digit level. Location is distinguished at the level of the 11 Standard Regions. Finally, the identification of a job is based on the question that asks whether or not the worker has spent more than 12 months in the current job with the present employer. Although this question may be more broadly interpreted, it is used in the empirical analysis to define a job and follow an individual over time within a job. The appendix reports on the abbreviations used throughout the paper.

Since the job-individual fixed effects mean that identification is achieved through job changes Table 1 reports the frequency of job changes by individuals in the sample. Individuals are in the panel for varying lengths of time, but almost $70 \%$ changed jobs at least once during the observation period. Figure 1 charts the incidence of overtime work over the period. Through the late 1970s and the 1980s the incidence of overtime work averaged $42 \%$, varying cyclically from a low of 36\% in 1981 to a high of 45\% in 1979 and 1990. Through the 1990s it has declined continuously, but in $199933 \%$ of men were still working paid overtime. The average number of overtime hours worked by those working overtime fluctuated within a relatively narrow range, between 8.4 and 9.2 hours per week (see figure 2). For those who work overtime, around 17 percent of their total hours of work are overtime hours, and this figure has been extremely stable. From Figure 3 it appears that actual hours worked have decreased roughly in parallel with standard hours over the observation period, although with greater cyclical variability. The persistent margin of overtime hours is clear. Table 2 gives further distributional details for overtime hours along with further sample statistics for selected years. The most notable feature is the sharp decline in union coverage. A further feature not shown is a minor decline in overtime incidence and overtime hours with age.

Tables 3 and 4 show the distribution of employees across occupations and industries along with the average incidence of overtime and share of overtime hours in these groups. The 
share of Managers and administrators (SOC1) has increased particularly sharply, while the share of employees who are in Craft and related jobs (SOC5) has declined. Among industrial sectors Distributive trades and catering (SIC7) and Banking, finance and business services (SIC9) have experienced rapid employment growth, while Metal goods and engineering products (SIC4) and Mineral extractions, metal and chemical products (SIC3) have declined. The main insight from these Tables is that most of the changes over time in the composition of the male labour force have been towards occupations and industries characterized by relatively low overtime incidence and overtime hours, and away from high-overtime jobs. ${ }^{7}$ Not shown here is that the change over the period in the incidence and share of overtime within occupations and industries appears relatively small compared to the differences between occupational and industries. The distribution of workers across regions changed only slightly over the period (Table 5), and the differences in overtime incidence and hours between regions are very small.

\section{The empirical framework}

The demand for hours depends, among other things, on wage rates, the fixed cost of labour and the overtime premium, see e.g. Calmfors and Hoel (1988). The supply of hours depends on the wage rate and workers' preferences over leisure and income. The approach taken in this paper is to consider a reduced form specification for overtime hours, where observed overtime hours are considered to be a combination of the supply of hours and demand for hours per worker. That is, the empirical model can identify the effects of explanatory variables on overtime but cannot identify whether these are demand or supply effects or a combination. This is of course also the case in all empirical studies mentioned in section 2. In addition, overtime hours may be the outcome of unobserved job-individual related characteristics. Furthermore, observed hours of work are censored at the level of contractual hours i.e. overtime hours are censored at zero when actual hours are equal to contractual hours.

In the empirical analysis the dependent variable is taken to be the share of overtime hours in total hours of work, denoted by $s h_{i t}$. The index $i$ denotes the individual in combination with a specific job and $t$ denotes the time period. That is, $\mathrm{N}$ individuals are observed over the

\footnotetext{
${ }^{7} \mathrm{An}$ issue not addressed here because of a lack of data on this is whether or not these new jobs are characterized by high unpaid overtime incidence and hours.
} 
sampling period with each individual $(n)$ having $J_{n}$ jobs over this period; this yields a total number of job-individuals equal to $\sum_{n=1, \ldots, N} J_{n}(\equiv I)$. The share of overtime hours is assumed to relate to the exogenous variables as follows:

$$
s h_{i t}=\max \left(0, \beta_{0, t}+X_{i t} \beta+\alpha_{i}+\varepsilon_{i t}\right), \quad i=1, . ., I, t=1, . ., T
$$

Where $\beta_{0, t}$ is a time-specific intercept parameter to control for calendar time effects, including cycle and trend, $\alpha_{\mathrm{i}}$ the unobserved job-individual specific effect, $\beta$ the effect of the exogenous variables on the share of overtime hours, and $\varepsilon_{\mathrm{it}}$ is a idiosyncratic error term. The max operator takes into account the truncation at $0 . \mathrm{X}_{\mathrm{it}}$ contains all time-varying and time-constant variables. The time-varying variables used in the empirical analysis are standard hours of work, the standard hourly wage rate, union status, age and age squared. The time constant variables (within a job) are the individual's occupational group, and the establishment's industry code and region.

From equation (1) two econometric difficulties arise that need to be discussed in more detail. Firstly the fact that overtime hours are observed only for those who work overtime and are equal to 0 otherwise, i.e. the truncation of overtime hours at 0 . Secondly, the possibility that the unobserved job-individual specific characteristics $\left(\alpha_{\mathrm{i}}\right)$ are correlated with the explanatory variables, due, for instance, to the omission of educational attainment or unobserved individualspecific preferences over work and leisure. Ignoring both these issues leads inconsistent parameter estimates, as noted in section 2. To solve the problem of truncation a Tobit model can be used (see Tobin, 1958). However, as a consequence of formulating a Tobit model the familiar 'within' estimator can no longer be employed to take into account possible correlation between the job-individual specific effects and the explanatory variables. To overcome this problem this paper adopts a panel data Tobit model as formulated in Kalwij (2000). Following Chamberlain (1984), he models the job-individual specific effect as a function of the explanatory variables. ${ }^{8}$ Specifically, in this paper it assumed that

\footnotetext{
${ }^{8}$ An alternative less parametric estimator for a panel data Tobit model with fixed effects is formulated by Honoré (1993). This estimator, however, does not identify the marginal effects and depends on the socalled conditional symmetry assumption that may be considered too restrictive in this particular study in which one wishes to allow for arbitrary serial correlation.
} 


$$
\alpha_{i}=\bar{X}_{i} \gamma+\mu_{i}, \quad \bar{X}_{i}=\frac{1}{T} \sum_{s=1}^{T} X_{i s}
$$

That is, the correlation between the job-individual specific effects and the explanatory variables is modelled explicitly as a function of the average over time of the explanatory variables plus a random job-individual specific effect that is assumed to be uncorrelated with the explanatory variables $\left(\mu_{i}\right)$. Intuitively, this parameterisation is quite appealing since in the absence of censoring, i.e. when a linear regression model can be estimated, it yields the familiar 'within' estimates (see Mundlak, 1978). In a censored panel data model, however, consistency does depend on correct parameterisation in equation (2). To alleviate the sensitivity of the parameter estimates with respect to this parameterisation Kalwij (2000) proposes a panel data Tobit model based on taking first differences of the equation of interest:

$$
\Delta s h_{i t}=\Delta \beta_{0, t}+\Delta X_{i t} \beta+\Delta \varepsilon_{i t}, \quad i=1, . ., I, t=2, . ., T .
$$

Although the job-individual specific effects no longer appear in equation (3) they are still present in the selection part of the model. So applying least squares to equation (3) on a sample of positive values of $s h_{i t-1}$ and $s h_{i t}$ would yield inconsistent estimates since $E\left[\Delta \varepsilon_{i t} \mid s h_{i t-1}^{*}>0, s h_{i t}^{*}>0\right] \neq 0$. This sample selection is taken into account in an estimation procedure similar to Tobin (1958). As with all estimators based on first differences, the cost of applying this estimator is that in the estimation one can use only those individuals observed within a job in two consecutive periods.

\subsection{The estimation procedure}

A Maximum Likelihood estimator is employed to estimate equation (3). As in the standard Tobit model, the error term $\varepsilon_{\mathrm{it}}$ is assumed to be Normally distributed with mean zero and variance $\sigma_{t}^{2}$ : $\varepsilon_{i t} \sim N\left(0, \sigma_{\varepsilon, t}^{2}\right)$. The random individual specific effect in equation (2), $\mu_{i}$, is assumed Normally distributed with mean zero and variance $\sigma_{\mu}^{2}, \mu_{i} \sim N\left(0, \sigma_{\mu}^{2}\right)$. Substituting equation (2) into equation (1) yields:

$$
s h_{i t}=\max \left(0, \beta_{0, t}+X_{i t} \beta+\bar{X}_{i} \gamma+u_{i t}\right), \quad i=1, . ., I, t=1, . ., T .
$$


Where $u_{i t}=\mu_{i}+\varepsilon_{i t}$ with, given the distributional assumptions, $u_{i t} \sim N\left(0, \sigma_{t}^{2}\right)$, $\sigma_{t}^{2}=\sigma_{\mu}^{2}+\sigma_{\varepsilon, t}^{2}$. Equation (3) remains unchanged but can be written as follows:

$$
\Delta s h_{i t}=\Delta \beta_{0, t}+\Delta X_{i t} \beta+\eta_{i t}, \quad i=1, . ., I, t=2, . ., T
$$

Where $\eta_{i t}=u_{i t}-u_{i t-1}\left(\equiv \varepsilon_{i t}-\varepsilon_{i t-1}\right)$.

The estimation is done in two steps in order to take into account arbitrary serial correlation. The correlation between $u_{i-1}$ and $u_{i t}$ is denoted by $\rho_{t}$. The probability of observing positive values of the share of overtime hours in both period $t-1$ and $t$ is given by:

$$
L_{i t}^{1}(\theta)=\Phi_{2}\left(\frac{\beta_{0, t-1}+X_{i t-1} \beta+\bar{X}_{i} \gamma}{\sigma_{t-1}}, \frac{\beta_{0, t}+X_{i t} \beta+\bar{X}_{i} \gamma}{\sigma_{t}}, \rho_{t}\right) \text {, }
$$

Where $\theta=\left(\beta_{0,1}, . ., \beta_{0, T}, \beta, \gamma, \sigma_{1}, . ., \sigma_{T}, \rho_{2}, . ., \rho_{T}\right)$ and $\Phi_{2}($.$) is the cumulative bivariate standard$ Normal distribution.

The truncated distribution of $\left(\Delta s h_{i t}-\Delta \beta_{0, t}-\Delta X_{i t} \beta\right)$ is given by (see Kalwij, 2000):

$$
\begin{aligned}
L_{i t}^{2}(\theta) & =\frac{1}{\sigma_{\eta, t}} \phi\left(\frac{\eta_{i t}}{\sigma_{\eta, t}}\right) \times \\
& \Phi\left(\min \left(\frac{\beta_{0, t-1}+X_{i t-1} \beta+\bar{X}_{i} \gamma+\frac{\sigma_{\eta t-1}}{\sigma_{\eta, t}^{2}} \eta_{i t}}{\sqrt{\sigma_{t-1}^{2}-\sigma_{\eta t-1}^{2} \sigma_{\eta, t}^{-2}}}, \frac{\beta_{0, t}+X_{i t} \beta+\bar{X}_{i} \gamma+\frac{\sigma_{\eta t}}{\sigma_{\eta, t}^{2}} \eta_{i t}}{\sqrt{\sigma_{t}^{2}-\sigma_{\eta t}^{2} \sigma_{\eta, t}^{-2}}}\right)\right)
\end{aligned}
$$

Where $\eta_{i t}=\Delta s h_{i t}-\Delta \beta_{0, t}-\Delta X_{i t} \beta, \sigma_{\eta, t}^{2}=\sigma_{t-1}^{2}-2 \rho_{t} \sigma_{t-1} \sigma_{t}+\sigma_{t}^{2}, \sigma_{\eta t-1}=\rho_{t} \sigma_{t-1} \sigma_{t}-\sigma_{t-1}^{2}$ and $\sigma_{\eta t}=\sigma_{t}^{2}-\rho_{t} \sigma_{t-1} \sigma_{t} . \Phi($.$) is the cumulative standard Normal distribution and \phi($.$) is the$ standard Normal density function. 
Based on equations (4) and (5), the Maximum Likelihood estimate of $\theta_{t}=\left(\Delta \beta_{0, t}, \beta_{t}, \gamma_{t}, \sigma_{t-1}, \sigma_{t}, \rho_{t}\right)$ is given by:

$$
\hat{\theta}_{t}=\underset{\theta}{\arg \max } \sum_{i=1}^{N}\left(1-I_{\left(y_{i t-1}>0, y_{i t}>0\right)}\right) \ln \left(1-L_{i t}^{1}\right)+I_{\left(y_{i t-1}>0, y_{i t}>0\right)} \ln \left(L_{i t}^{2}\right)
$$

Maximum Likelihood is applied to each period $(t=2, \ldots, T)$ and next a Minimum Distance estimator is employed to impose the restriction $\left\{\beta_{t}=\beta\right.$ and $\left.\gamma_{t}=\gamma, \forall t\right\}$ using the optimal weighting matrix. As in a fixed effects model only the $\beta$ parameters corresponding to the time varying regressors are identified. For the time constant regressors only the sum (say, $\beta_{2}+\gamma_{2}$ ) is identified. The reported pseudo $\mathrm{R}^{2}$ is defined as the square of the correlation between the expected share of overtime hours, i.e. the expectation of equation (1'), and observed overtime hours.

Under the assumption of a correctly parameterised job-individual specific effect and, as in the standard Tobit model, Normally distributed error terms, this approach yields consistent parameter estimates. Thus this model overcomes the problems in the econometric specifications of the previous studies discussed in section 2 and allows for both censoring of overtime hours and job-individual specific effects by fully exploiting the fact that panel data are available.

\subsection{Business cycle effects}

Figures 1 to 4 show that overtime incidence and hours are affected by the business cycle, showing a pro-cyclical movement over time. Although the variation over time due to possible business cycle effects is relatively small, it is important to control for these in order to assess whether overtime hours are decreasing over time. For this purpose an approach is taken similar to that of Behrman and Birdsall (1988) who analyse wage rates modelling calendar time effects as a function of macroeconomic indicators of the business cycle. The de-trended real gross domestic product $\left(R G D P_{t}\right)$ and the unemployment rate $\left(U R_{t}\right)$ are used as macroeconomic indicators. These variables are shown in figures 5 and 6 . The employer's response to a positive productivity shock may be to increase the hours worked by the current workforce; hence a positive coefficient on this variable is expected. The unemployment rate is used as an indicator of the degree of tightness in the labour market. Hence, if one expects that when the labour market is tight, i.e. unemployment is low, firms are forced to respond to fluctuations in product demand by using 
more overtime rather than hiring more workers, then the coefficient on this variable is expected to have a negative sign.

The relationship between these two macroeconomic variables and the calendar time effects is assumed to be as follows:

$$
\beta_{0, t}=\theta_{0}+\theta_{1} t+\theta_{2} t^{2}+\theta_{3} \ln \left(R G D P_{t}\right)+\theta_{4} U R_{t}+\zeta_{t} \quad t=1, . ., T
$$

Equation (7) is estimated by the Minimum Distance procedure. ${ }^{9}$

\section{$5 \quad$ Empirical Results}

Table 6 reports the estimation results. Looking first at the job-individual effects, Table 6 shows that individuals in jobs classified to occupations SOCs 5, 6 and 7 (Craft and Related; Personal and Protective Services; Plant and Machine Operatives) work the largest relative amounts of overtime. Differences in overtime work across industries are relatively small, except for the high level in SIC8 (Transport and Communications). Regional differences are found to be very small. The extent of overtime working is unaffected by the individual's age. Contrary to the visual impression from figures 1 and 2 the downward trend in overtime hours begins in the early 1980s, but becomes noticeable only in the last few years of the period; again contrary to the visual impression, the effect is always small and a decrease only sets in after 1996. In fact the estimation results (the p.e.'s of trend and trend squared) suggest an increase of about 2 percentage points over the entire period 1975-99 after controlling for the business cycle and job composition. The main reason for the observed reduction in overtime (figures 1 and 2) is a compositional effect: the substitution away from jobs with paid overtime hours to jobs with no paid overtime hours (see also tables 3 and 4).

Turning to the time varying explanatory variables, the parameter estimates on the time averages show that individuals in union covered jobs work more paid overtime. However, the effect of de-unionisation on overtime work appears to be relatively small (p.e. is 0.0017) suggesting that union coverage is related to the type of job rather than it affecting overtime

\footnotetext{
${ }^{9} \theta_{l}$ and $\theta_{2}$ are true calendar time effects only under the assumption of no birth-cohort effects.
} 
hours. Jobs with relatively high contractual hours of work are characterized by more hours of paid overtime. Low wage jobs do not appear to be associated with overtime work (p.e. 0.0012 and insignificant). A $1 \%$ increase in the wage rate causes a decrease in the share of overtime hours of about $0.1 \%$ (p.e. is -0.0193 ). This implies from a supply side perspective that the income effect dominates the substitution effect, or from the demand side that firms substitute away from hours when wages increase. As mentioned in section 4, only the sum of the demand and supply effects is identified in this model and the overall effect of a change in the wage rate on total working hours is found to be very small (an elasticity of about -0.024). A reduction in contractual hours is associated with an increase in the share of overtime work. The elasticity of total working hours with respect to contractual hours is about 0.98 . This is very close to the figure found in the other empirical studies discussed in section 2, and confirms that a reduction in contractual hours does lower actual hours, and that the elasticity is close to 1. This is not, however, evidence in favour of a policy to reduce working hours in order to increase employment since the analysis in this paper is conditional on total labour demand (see, e.g. Kapteyn et al., 2000 , for a discussion on work-sharing policies).

The business cycle, as measured by fluctuations in GDP around trend, has a large impact on overtime work. A $1 \%$ movement above trend is associated with $1.2 \%$ rise in overtime. The unemployment rate, on the other hand, has virtually no impact. These results are in line with the 'business cycle facts' emphasised in macroeconomics, that whole-economy total hours worked are at least as volatile as output, and divide between hours and employment with hours tending to lead, and employment to lag, the output cycle (see e.g. Millard, Scott and Sensier, 1997). This suggestion that productivity shocks are dealt with in the first instance by expanding hours of work, with employment effects occurring rather later, is confirmed by the pattern in the correlation coefficient in figure 7 . The average correlation is negative and equal to -0.33 , suggesting that a job specific shock in overtime work is compensated by a reduction in the next period.

\section{Conclusions}

This paper has made two innovations in its analysis of overtime work in Britain over the past 25 years. The extent of overtime work is viewed as the outcome of both demand and supply influences encapsulated in job-individual effects, related to the individual within a particular job. 
A new estimation method as been applied, allowing for the truncation of overtime hours at zero in a model with job/individual specific effects and allowing for correlation between these and the included explanatory variables. Hence identification of the elasticities of overtime hours with respect to standard hours, wage rates and union status is based solely on within job changes.

Three important conclusions emerge from the analysis. Changes in the job-mix across the economy, from high to low overtime jobs rather than within-job changes in the use of overtime, account for most of the apparent decline in the extent of overtime working over the 1990s. Within jobs, the GDP cycle has a significant impact on overtime work, while labour market conditions, represented by the unemployment rate, do not. The elasticity of total hours with respect to wages is found to be close to zero. The elasticity of total hours with respect to contractual hours is positive and very close to unity; reducing the length of the standard workweek reduces working time to approximately the same extent. While deregulation and the decline of unionisation have changed the British labour market in many ways, it is structural change rather than institutional change that is altering the use of overtime.

\section{Acknowledgements}

We wish to thank the seminar participants of the Leverhulme Trust meeting at the University of Essex, the Centre for Economic Performance (CEP) at the London School of Economics and the Institute for the Study of Labor (IZA) in Bonn for extremely useful comments and discussion.

\section{References}

Bauer, T. and K.F. Zimmermann (1999). 'Overtime Work and Overtime Compensation in Germany', Scottish Journal of Political Economy, 46, 419-436.

Behrman, J.R., and N. Birdsall (1988). 'The Reward for Good Timing: Cohort Effects and Earnings Functions for Brazilian Males', The Review of Economics and Statistics, Vol.70, Issue 1, 129-135.

Bell, D.N.F. and R.A. Hart (1998). 'Working Time in Great Britain, 1975-1994', Journal of the Royal Statistical Society, Series A, Vol. 161, part 3, pp 327-348. 
Bell, D.N.F. and R.A. Hart (1999). 'Overtime working in an unregulated labor market', IZA discussion paper, no. 44, Institute for the Study of Labor, Bonn.

Calmfors, L. and M. Hoel (1988). 'Worksharing and overtime', Scandinavian Journal of Economics, 90 (1), 45-52.

Chamberlain, G. (1984). 'Panel Data', in Z. Griliches and M.D. Intriligator (eds), Handbook of Econometrics, Vol. II, North-Holland, Amsterdam, 1247-1318.

Honoré, B.E. (1992). 'Trimmed LAD and Least Squares estimation of truncated and censored regression models with fixed effects', Econometrica, 60, 533-565

Hunt, J. (1999). 'Has work-sharing worked in Germany?', The Quarterly Journal of Economics, 117-148.

Kalwij, A. (2000). 'A Maximum Likelihood Estimator Based on First Differences for a Panel Data Tobit Model with Individual Specific Effects', CenER discussion paper, 28, Tilburg University.

Kapteyn. A., A. Kalwij and A. Zaidi (2000). 'The Myth of Worksharing', CenER discussion paper, 23, Tilburg University.

Lilien, D.M., and R.E. Hall (1986). 'Cyclical fluctuations in the labor market', Chapter 17 in Handbook of Labor Economics, Vol.II, editors: O.Ashenfelter and R. Layard, Elsevier Science Publishers, Amsterdam.

Millard, S., A. Scott and M. Sensier (1997). 'The labour market over the business cycle: Can theory fit the facts?', Oxford Review of Economics Policy, 13 (3), 70- 92.

Mundlak, Y. (1978). 'On the Pooling of Time Series and Cross Section Data', Econometrica, 46, 69-86.

Nickell, S.J. (1983). 'Working hours in Britain', mimeo, Centre for Labour Economics.

Tobin, J. (1958). 'Estimation of relationships for limited dependent variables', Econometrica, 26, 24-36.

Trejo, S.J. (1991). 'The Effects of Overtime Pay Regulation on Worker Compensation', American Economic Review, 81 (4), 720-740.

Trejo, S.J. (1993). 'Overtime Pay, Overtime Hours, and Labor Unions', Journal of Labor Economics, 11 (2), 253-278. 
Appendix: Definitions of the abbreviations.

\begin{tabular}{ll}
\hline Region & Dummy variable \\
\hline Greater London & REG1 \\
South-East (excluding Greater London) & REG2 \\
East Anglia & REG3 \\
South West & REG4 \\
West Midlands & REG5 \\
East Midlands & REG6 \\
Yorkshire \& Humberside & REG7 \\
North West & REG8 \\
North & REG9 \\
Wales & REG10 \\
Scotland & REG11 \\
\hline
\end{tabular}

\begin{tabular}{ll}
\hline Industry Status & Dummy variable \\
\hline Agriculture & SIC1 \\
Energy and water supply & SIC2 \\
Mineral extractions, metal and chemical products & SIC3 \\
Metal goods and engineering products & SIC4 \\
Other manufacturing industries & SIC5 \\
Construction & SIC6 \\
Distributive trades and catering & SIC7 \\
Transport and communications & SIC8 \\
Banking, finance and business services & SIC9 \\
Other services & SIC10 \\
\hline
\end{tabular}

\begin{tabular}{ll}
\hline Occupational Status & Dummy variable \\
\hline Managers and administrators & SOC1 \\
Professional & SOC2 \\
Associate professional and technical & SOC3 \\
Clerical and secretarial & SOC4 \\
Craft and related occupations & SOC5 \\
Personal and protective services & SOC6 \\
Sales & SOC7 \\
Plant and machine operatives & SOC8 \\
Other & SOC9 \\
\hline
\end{tabular}


Table 1: Number of jobs per individual (percentages)

\begin{tabular}{lllllllll}
\hline Number of jobs & 1 & 2 & 3 & 4 & 5 & 6 & 7 & $>7$ \\
\hline \% workers & 31.3 & 25.8 & 18.8 & 11.8 & 6.6 & 3.3 & 1.5 & 0.9 \\
\hline
\end{tabular}

Table 2: Sample statistics, selected years

\begin{tabular}{|c|c|c|c|c|c|c|}
\hline Variables & '76 & '80 & '85 & '90 & '95 & '99 \\
\hline Age & 41.2 & 40.6 & 40.0 & 40.1 & 39.9 & 40.8 \\
\hline Union Status & 0.59 & 0.50 & 0.50 & 0.36 & 0.28 & 0.22 \\
\hline Overtime incidence & 0.42 & 0.42 & 0.42 & 0.43 & 0.38 & 0.33 \\
\hline Share of Overtime hours & 0.17 & 0.18 & 0.17 & 0.17 & 0.17 & 0.16 \\
\hline \multicolumn{7}{|l|}{ (If working overtime) } \\
\hline \multicolumn{7}{|c|}{ Distribution of overtime hours (If working overtime) } \\
\hline Mean & 8.92 & 9.75 & 8.80 & 9.23 & 8.96 & 8.42 \\
\hline $10^{\text {th }}$ Percentile & 1.84 & 1.84 & 1.50 & 1.50 & 1.26 & 1.25 \\
\hline $50^{\text {th }}$ Percentile & 7.37 & 7.60 & 7.00 & 7.28 & 6.62 & 6.00 \\
\hline $90^{\text {th }}$ Percentile & 18.1 & 19.4 & 18.3 & 19.8 & 19.8 & 18.7 \\
\hline \multicolumn{7}{|c|}{ Distribution of standard hours } \\
\hline Mean & 38.7 & 38.5 & 37.9 & 37.9 & 37.9 & 37.8 \\
\hline $10^{\text {th }}$ Percentile & 36 & 35 & 35 & 35 & 35 & 35 \\
\hline $50^{\text {th }}$ Percentile & 40 & 40 & 38.3 & 38 & 37.5 & 37.5 \\
\hline $90^{\text {th }}$ Percentile & 40 & 40 & 40 & 40 & 40 & 40 \\
\hline \multicolumn{7}{|c|}{ Distribution of the basic hourly wage rate } \\
\hline Mean & 7.18 & 7.20 & 8.13 & 9.99 & 10.3 & 11.1 \\
\hline $10^{\text {th }}$ Percentile & 4.32 & 4.20 & 4.42 & 4.70 & 4.81 & 5.05 \\
\hline $50^{\text {th }}$ Percentile & 6.38 & 6.37 & 7.04 & 7.90 & 8.45 & 9.04 \\
\hline $90^{\text {th }}$ Percentile & 11.0 & 11.1 & 13.1 & 15.5 & 17.4 & 18.8 \\
\hline
\end{tabular}


Table 3: Occupational Status.

$\mathrm{OI}=$ overtime incidence, $\mathrm{SOH}=$ share of overtime hours in total working hours

\begin{tabular}{|c|c|c|c|c|c|c|c|c|}
\hline & \multirow[t]{2}{*}{ OI } & \multirow[t]{2}{*}{$\mathrm{SOH}$} & \multicolumn{6}{|c|}{$\%$ of observations per category within a year } \\
\hline & & & 76 & '80 & '85 & '90 & '95 & '99 \\
\hline SOC1 & 0.11 & 0.13 & 6.7 & 7.7 & 8.0 & 9.9 & 14.4 & 16.6 \\
\hline SOC2 & 0.16 & 0.13 & 11.5 & 11.6 & 12.4 & 12.6 & 11.5 & 11.6 \\
\hline SOC3 & 0.23 & 0.13 & 7.1 & 7.8 & 8.9 & 9.4 & 9.3 & 8.7 \\
\hline SOC4 & 0.38 & 0.14 & 10.7 & 10.1 & 10.5 & 10.1 & 10.4 & 10.0 \\
\hline SOC5 & 0.52 & 0.17 & 26.7 & 25.7 & 23.3 & 21.9 & 19.1 & 16.9 \\
\hline SOC6 & 0.52 & 0.15 & 4.6 & 5.1 & 6.0 & 5.8 & 6.2 & 7.1 \\
\hline SOC7 & 0.19 & 0.16 & 3.4 & 3.3 & 4.1 & 4.0 & 4.5 & 5.0 \\
\hline SOC8 & 0.60 & 0.19 & 19.9 & 19.9 & 18.2 & 17.9 & 16.5 & 16.2 \\
\hline SOC9 & 0.57 & 0.20 & 9.4 & 8.7 & 8.7 & 8.5 & 8.0 & 7.9 \\
\hline & & & 100 & 100 & 100 & 100 & 100 & 100 \\
\hline
\end{tabular}

Table 4: Industry Status.

$\mathrm{OI}=$ overtime incidence, $\mathrm{SOH}=$ share of overtime hours in total working hours

\begin{tabular}{|c|c|c|c|c|c|c|c|c|}
\hline & \multirow[t]{2}{*}{ OI } & \multirow[t]{2}{*}{$\mathrm{SOH}$} & \multicolumn{6}{|c|}{$\%$ of observations per category within a year } \\
\hline & & & 76 & ' 80 & '85 & '90 & '95 & ‘99 \\
\hline SIC1 & 0.55 & 0.20 & 1.5 & 1.5 & 1.4 & 1.4 & 1.3 & 1.2 \\
\hline SIC2 & 0.41 & 0.16 & 5.3 & 5.1 & 5.1 & 4.6 & 2.9 & 2.2 \\
\hline SIC3 & 0.42 & 0.18 & 8.1 & 7.8 & 6.6 & 6.5 & 5.7 & 4.5 \\
\hline SIC4 & 0.50 & 0.17 & 21.0 & 20.5 & 18.4 & 18.3 & 16.8 & 15.9 \\
\hline SIC5 & 0.44 & 0.18 & 11.8 & 11.2 & 10.8 & 11.1 & 11.3 & 10.3 \\
\hline SIC6 & 0.43 & 0.18 & 8.3 & 8.0 & 7.4 & 6.8 & 5.7 & 5.5 \\
\hline SIC7 & 0.32 & 0.16 & 8.6 & 10.1 & 10.9 & 11.4 & 13.2 & 15.1 \\
\hline SIC8 & 0.57 & 0.20 & 12.7 & 11.9 & 11.2 & 10.4 & 9.7 & 9.3 \\
\hline SIC9 & 0.25 & 0.12 & 4.8 & 5.7 & 7.2 & 10.1 & 12.1 & 13.5 \\
\hline \multirow[t]{2}{*}{ SIC10 } & 0.28 & 0.15 & 18.0 & 18.3 & 21.1 & 19.5 & 21.3 & 22.5 \\
\hline & & & 100 & 100 & 100 & 100 & 100 & 100 \\
\hline
\end{tabular}


Table 5: Region

$\mathrm{OI}=$ overtime incidence, $\mathrm{SOH}=$ share of overtime hours in total working hours

\begin{tabular}{lrrrrrrrrr}
\hline & OI & \multicolumn{7}{c}{ SOH } & \multicolumn{7}{c}{ \% observations per category within a year } \\
\hline & & & & \multicolumn{1}{c}{76} & \multicolumn{1}{c}{ '80 } & \multicolumn{1}{c}{ '85 } & '90 & '95 & \multicolumn{1}{c}{99} \\
REG1 & 0.35 & 0.17 & 15.8 & 15.6 & 15.7 & 15.1 & 14.5 & 14.1 \\
REG2 & 0.40 & 0.17 & 15.1 & 15.3 & 16.1 & 16.5 & 16.6 & 17.1 \\
REG3 & 0.44 & 0.17 & 3.4 & 3.3 & 3.5 & 3.7 & 4.1 & 4.3 \\
REG4 & 0.39 & 0.16 & 7.4 & 7.6 & 8.0 & 8.2 & 8.2 & 8.4 \\
REG5 & 0.41 & 0.17 & 9.6 & 10.1 & 9.6 & 10.5 & 9.8 & 10.4 \\
REG6 & 0.44 & 0.17 & 6.8 & 7.1 & 6.9 & 7.2 & 7.8 & 8.1 \\
REG7 & 0.42 & 0.17 & 9.8 & 9.5 & 9.3 & 9.5 & 9.5 & 9.7 \\
REG8 & 0.41 & 0.17 & 12.0 & 11.9 & 11.7 & 11.1 & 11.1 & 10.7 \\
REG9 & 0.40 & 0.17 & 4.5 & 4.7 & 4.4 & 4.2 & 4.3 & 4.0 \\
REG10 & 0.38 & 0.17 & 5.0 & 4.5 & 4.6 & 4.7 & 4.6 & 4.5 \\
REG11 & 0.41 & 0.17 & 10.7 & 10.4 & 10.2 & 9.3 & 9.5 & 8.8 \\
& & & 100 & 100 & 100 & 100 & 100 & 100 \\
\hline
\end{tabular}


Table 6: Estimation results. Dependent variable is the share of overtime hours in total working hours.*

\begin{tabular}{|c|c|c|c|c|c|}
\hline Explanatory variables & p.e. & s.e. & & p.e. & s.e. \\
\hline Constant & -0.0321 & 0.0032 & & & \\
\hline Ln(Real GDP per worker) & 0.2043 & 0.0157 & & & \\
\hline Unemployment rate & -0.0018 & 0.0001 & & & \\
\hline Trend $(\mathrm{t}=0, . ., \mathrm{T})$ & 0.0022 & 0.0002 & & & \\
\hline Trend squared & $-5.1 \times 10^{-5}$ & $6.5 \times 10^{-6}$ & & & \\
\hline Age & $7.7 \times 10^{-6}$ & $1.9 \times 10^{-5}$ & & & \\
\hline Age squared & $1.8 \times 10^{-7}$ & $4.5 \times 10^{-7}$ & & & \\
\hline & & & & \multicolumn{2}{|c|}{ Time Average } \\
\hline Ln(standard hours) & -0.0204 & 0.0008 & & 0.0352 & 0.0011 \\
\hline Ln(standard wage rate) & -0.0193 & 0.0008 & & 0.0012 & 0.0008 \\
\hline Union status & 0.0017 & 0.0006 & & 0.0040 & 0.0007 \\
\hline \multicolumn{6}{|l|}{ Occupation } \\
\hline SOC1 & - & & & & \\
\hline SOC2 & 0.0147 & 0.0004 & SOC6 & 0.0777 & 0.0007 \\
\hline SOC3 & 0.0254 & 0.0004 & SOC7 & 0.0100 & 0.0007 \\
\hline SOC4 & 0.0425 & 0.0005 & SOC8 & 0.0709 & 0.0006 \\
\hline SOC5 & 0.0590 & 0.0005 & SOC9 & 0.0613 & 0.0006 \\
\hline \multicolumn{6}{|l|}{ Industry } \\
\hline SIC1 & - & & SIC6 & -0.0092 & 0.0005 \\
\hline SIC2 & -0.0087 & 0.0006 & SIC7 & -0.0167 & 0.0005 \\
\hline SIC3 & -0.0080 & 0.0005 & SIC8 & 0.0113 & 0.0005 \\
\hline SIC4 & 0.0020 & 0.0005 & SIC9 & -0.0130 & 0.0006 \\
\hline SIC5 & -0.0073 & 0.0005 & SIC10 & -0.0258 & 0.0006 \\
\hline \multicolumn{6}{|l|}{ Region } \\
\hline REG1 & - & & & & \\
\hline REG2 & 0.0020 & 0.0002 & REG7 & -0.0038 & 0.0003 \\
\hline REG3 & -0.0008 & 0.0004 & REG8 & -0.0066 & 0.0003 \\
\hline REG4 & -0.0047 & 0.0003 & REG9 & -0.0097 & 0.0004 \\
\hline REG5 & -0.0059 & 0.0027 & REG10 & -0.0127 & 0.0004 \\
\hline REG6 & -0.0027 & 0.0003 & REG11 & -0.0053 & 0.0003 \\
\hline$\rho_{\mathrm{t}}($ mean group estimate $)$ & -0.3297 & 0.0395 & & & \\
\hline$\sigma_{t}($ mean group estimate) & 0.1061 & 0.0216 & & & \\
\hline Pseudo $\mathrm{R}^{2}$ & 0.132 & & & & \\
\hline
\end{tabular}

* p.e. $=$ parameter estimates, s.e. $=$ standard error. 
Figure 1: Overtime Incidence
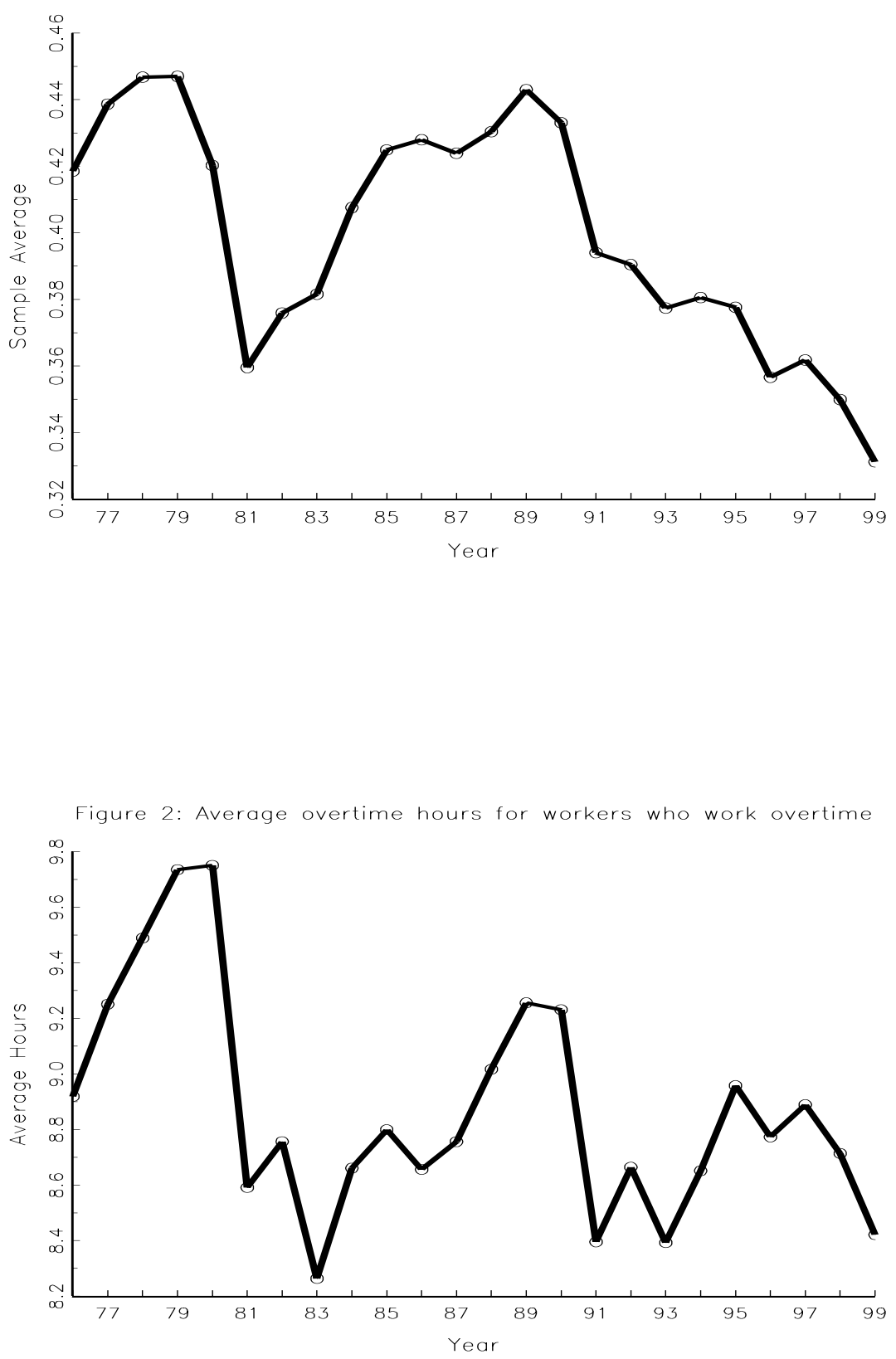

20 


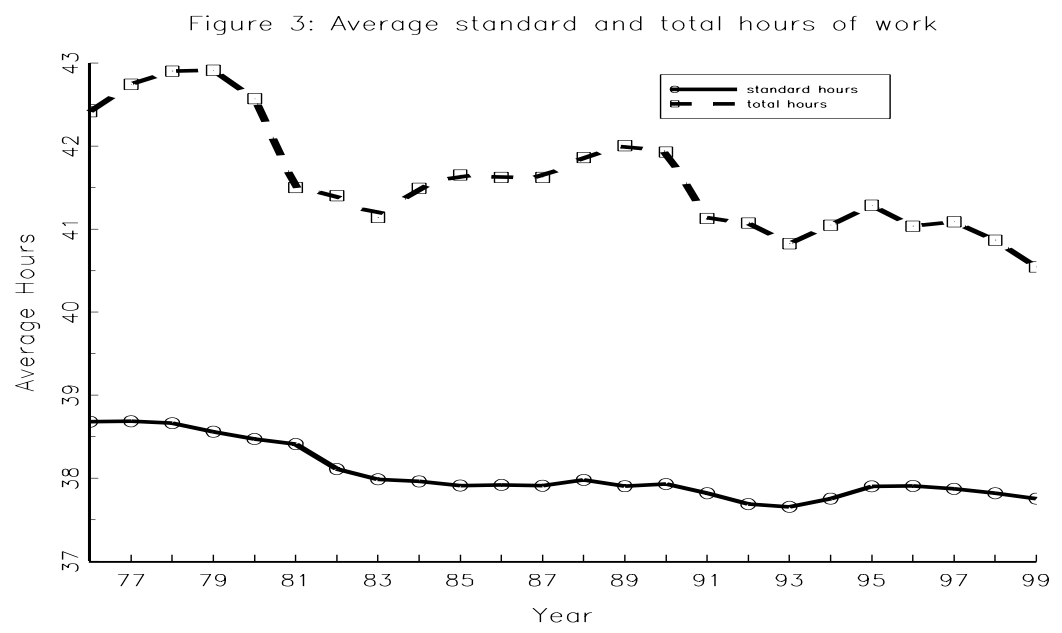

Figure 4: Average share of overtime hours for worker who work overtime

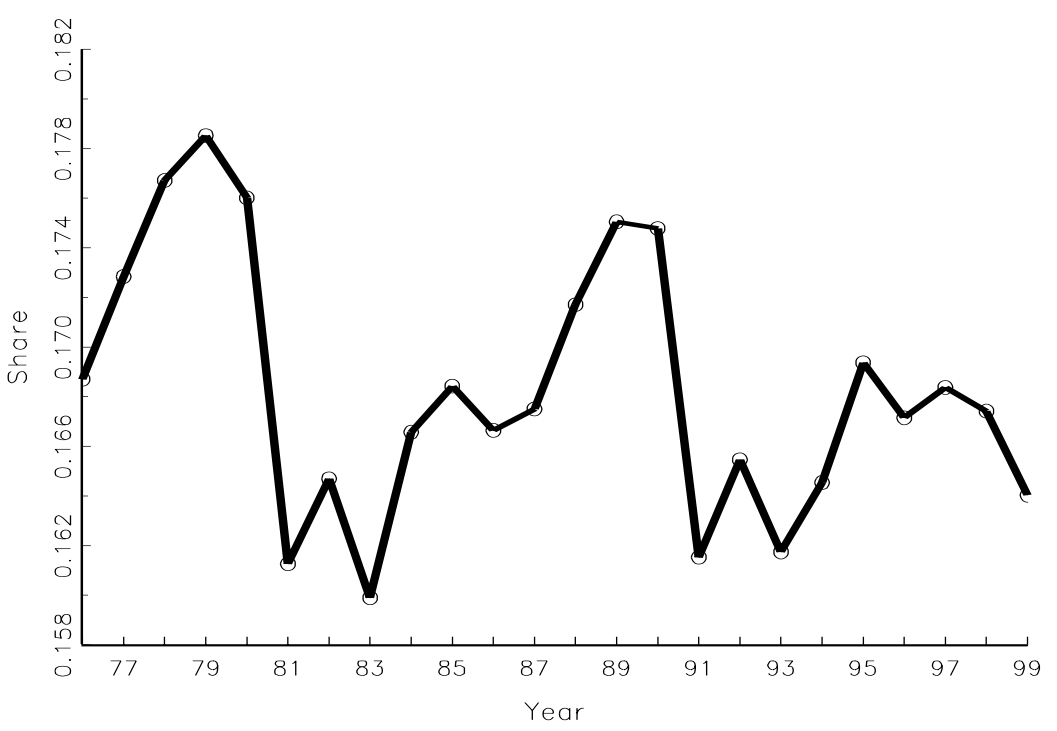

21 
$M$

W 


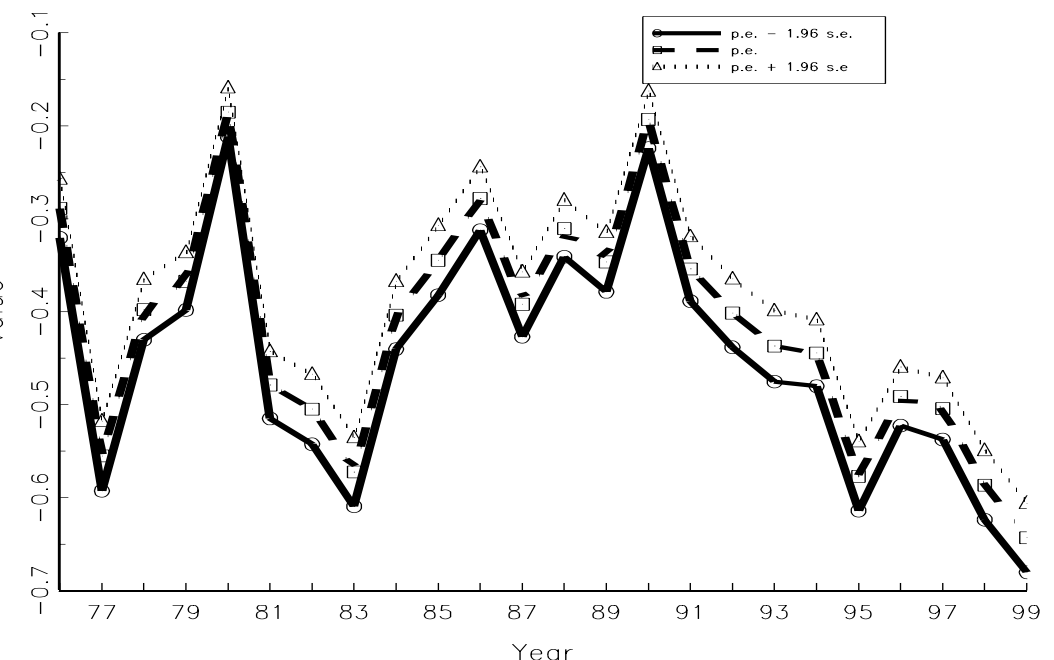




\section{IZA Discussion Papers}

No. Author(s)

51

A. Barrett

P. J. O'Connell

52 J. Mayer

R. T. Riphahn

53

J. Hartog

P. T. Pereira

J. A. C. Vieira

54 M. Lofstrom

55

L. Goerke

56

A. Lindbeck

D. J. Snower

57

I. N. Gang

K. F. Zimmermann

58

T. Bauer

K. F. Zimmermann

59

D. J. DeVoretz

S. A. Laryea

60

C. Belzil

J. Hansen

61

R. Winkelmann

62

A. Thalmaier

63

M. Ward

64

M. Ward

65

H. Lehmann

J. Wadsworth

A. Acquisti

66

E. J. Bird

H. Kayser

J. R. Frick

G. G. Wagner
Title

Area

Date

Does Training Generally Work?

5

$8 / 99$

The Returns to In-Company Training

Fertility Assimilation of Immigrants: Evidence

3

$8 / 99$

from Count Data Models

Inter-industry Wage Dispersion in Portugal: high

but falling

$8 / 99$

Labor Market Assimilation and the

$8 / 99$

Self-Employment Decision of Immigrant

Entrepreneurs

Value-added Tax versus Social Security

Contributions

Centralized Bargaining and Reorganized Work:

Are they compatible?

Is Child like Parent?

Educational Attainment and Ethnic Origin

9/99

Occupational Mobility of Ethnic Migrants

$9 / 99$

Canadian Immigration Experience:

Any Lessons for Europe?

Subjective Discount Rates, Intergenerational

Transfers and the Return to Schooling

Immigration: The New Zealand Experience

$10 / 99$

Bestimmungsgründe von Fehlzeiten: Welche

Rolle spielt die Arbeitslosigkeit?

1/2/3 9/99

6

$10 / 99$

Your Everyday, Average Academic

$10 / 99$

Salary and the Gender Salary Gap in the Academic Profession

Grime and Punishment: Job Insecurity and Wage 4

Arrears in the Russian Federation

$10 / 99$

The Immigrant Welfare Effect: Take-Up or

3

$10 / 99$ 

of Wage Differentials Transition Economies

\section{0 \\ J. C. van Ours}

J. Veenman
The Netherlands: Old Emigrants - Young Immigrant Country

Migration, Migrants and Policy in the United Kingdom

Privacy, time consistent optimal labor income taxation and education policy

Female Labour Supply, Flexibility of Working Hours, 1 and Job Mobility in the Netherlands

The Heterogeneity and Cyclical Sensitivity of 1 Unemployment: An Exploration of German Labor Market Flows 

Adversity

91 M. Lechner

Tenures that Shook the World: Worker Turnover in $\quad 4$ Russia, Poland and Britain

Identification and Estimation of Causal Effects of

An Evaluation of Public-Sector-Sponsored

Continuous Vocational Training Programs in East

N. Smith 
107 J. C. van Ours G. Ridder

J. Boone

J. C. van Ours

109 G. J. van den Berg

B. van der Klaauw

110 D. DeVoretz

C. Werner

111 V. Sorm

K. Terrell

L. Bellmann

T. Schank

113 R. Euwals

114 G. Brunello

A. Medio

115 A. Cigno

F. C. Rosati

116

C. Belzil

A. Haas

C. Klose

118 M. A. Shields

M. E. Ward

119 A. Lindbeck

D. J. Snower

120 P. T. Pereira

P. S. Martins

121 J. C. van Ours
Fast Track or Failure: A Study of the Completion

Rates of Graduate Students in Economics

Modeling Financial Incentives to Get Unemployed Back to Work

Combining Micro and Macro Unemployment

3

$1 / 00$

Duration Data

A Theory of Social Forces and Immigrant Second

1

$2 / 00$

Language Acquisition

Sectoral Restructuring and Labor Mobility:

A Comparative Look at the Czech Republic

Innovations, Wages and Demand for

5

$2 / 00$

Heterogeneous Labour: New Evidence from a

Matched Employer-Employee Data-Set

Do Mandatory Pensions Decrease Household

Savings? Evidence for the Netherlands

An Explanation of International Differences in

Education and Workplace Training

Why do Indian Children Work, and is it Bad for

3

$2 / 00$

Them?

Unemployment Insurance and Subsequent Job

3

$2 / 00$

Duration: Job Matching vs. Unobserved

Heterogeneity

IAB Employment Subsample 1975-1995.

Opportunities for Analysis Provided by the

Anonymised Subsample

Improving Nurse Retention in the British National

5

$2 / 00$

Health Service: The Impact of Job Satisfaction on Intentions to Quit

The Division of Labor and the Market for

Organizations

Does Education Reduce Wage Inequality?

5

Quantile Regressions Evidence from Fifteen

European Countries

Do Active Labor Market Policies Help Unemployed Workers to Find and Keep Regular Jobs? 
Rational Poverty or Poor Rationality? The Take-up of Social Assistance Benefits

125 F. Büchel

The Income Portfolio of Immigrants in Germany -

Effects of Ethnic Origin and Assimilation. Or:

J. R. Frick

126 J. Fersterer

R. Winter-Ebmer

Who Gains from Income Re-Distribution?

127 M. Karanassou

D. J. Snower

Smoking, Discount Rates, and Returns to

Education

Characteristics of Unemployment Dynamics: The

Chain Reaction Approach

128 O. Ashenfelter

D. Ashmore

O. Deschênes

Do Unemployment Insurance Recipients Actively

Seek Work? Evidence From Randomized Trials in

Four U.S. States

129 B. R. Chiswick

M. E. Hurst

C. Lucifora

The Employment, Unemployment and Unemployment Compensation Benefits of Immigrants

The Returns to Education in Italy: A New Look at the Evidence

Are Immigrants Favorably Self-Selected? An

134 A. D. Kugler

G. Saint-Paul

135 A. Barrett P. J. O'Connell

136 M. Bräuninger M. Pannenberg

Is There a Wage Premium for Returning Irish

Unemployment and Productivity Growth: An

Empirical Analysis within the Augmented Solow 
141 R. Hujer

M. Wellner

142

J. J. Dolado

F. Felgueroso

J. F. Jimeno

143 P. J. Luke

M. E. Schaffer

144 G. Saint-Paul

145 M.-S. Yun

146 T. K. Bauer

J. P. Haisken-DeNew

147 M. Belot

J. C. van Ours

148 L. Goerke

149 R. Lalive

J. C. van Ours

J. Zweimüller

150 J. DiNardo

K. F. Hallock

J.-St. Pischke

151 M. Ward

152 J. J. Dolado

F. Felgueroso

J. F. Jimeno

153 A. S. Kalwij

M. Gregory
The Effects of Public Sector Sponsored Training on

Individual Employment Performance in East

Germany

Explaining Youth Labor Market Problems in Spain: 3

Crowding-Out, Institutions, or Technology Shifts?

Wage Determination in Russia: An Econometric

Investigation

Flexibility vs. Rigidity: Does Spain have the worst of 1 both Worlds?

Decomposition Analysis for a Binary Choice Model 7

Employer Learning and the Returns to Schooling

5

Does the Recent Success of Some OECD

Countries in Lowering their Unemployment Rates

Lie in the Clever Design of their Labour Market

Reforms?

Employment Effects of Labour Taxation in an Efficiency Wage Model with Alternative Budget

Constraints and Time Horizons

The Impact of Active Labor Market Programs and

Benefit Entitlement Rules on the Duration of Unemployment

Unions and the Labor Market for Managers

7

Gender, Salary and Promotion in the Academic Profession

The Role of the Minimum Wage in the Welfare 3

State: An Appraisal

Overtime Hours in Great Britain over the Period 3

1975-1999: A Panel Data Analysis
$4 / 00$

$4 / 00$

$5 / 00$

$5 / 00$

$4 / 00$

$4 / 00$

$4 / 00$

$4 / 00$

$4 / 00$

$5 / 00$

$5 / 00$

$5 / 00$

$5 / 00$

An updated list of IZA Discussion Papers is available on the center's homepage www.iza.org. 